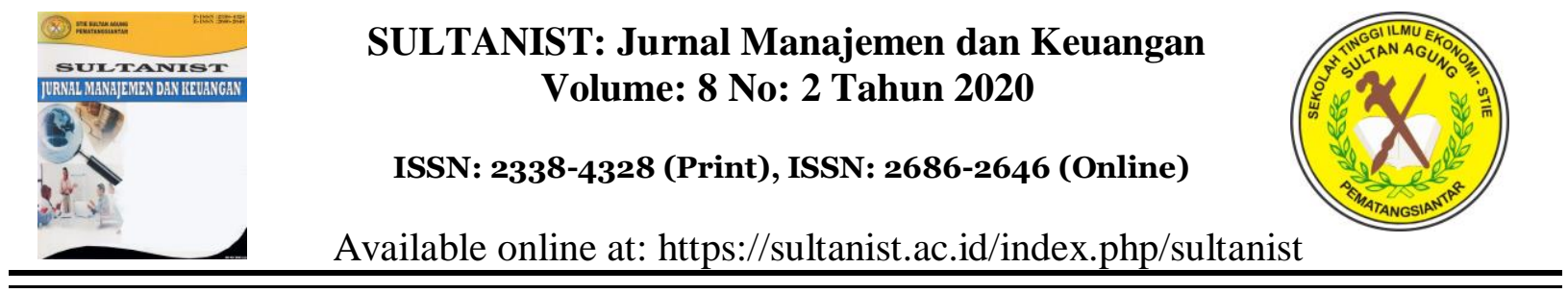

\title{
ANALISIS TREND PENERIMAAN DAN EFEKTIVITAS PAJAK HOTEL DAN PAJAK RESTORAN DI KABUPATEN BOJONEGORO TAHUN 2016- 2020 (Studi Kasus pada Dinas Pendapatan Daerah Kabupaten Bojonegoro)
}

\author{
Edy Anas Ahmadi ${ }^{1)}$ \\ ${ }^{1}$ Program Studi Manajemen, Sekolah Tinggi Ekonomi Islam Permata Bojonegoro \\ *E-mail: ${ }^{1}$ ganeks1@gmail.com
}

\begin{abstract}
Abstrak
Penelitian ini bertujuan untuk menganalisis trend penerimaan dan efektivitas pajak hotel dan pajak restoran di Kabupaten Bojonegoro pada tahun 2016-2020. Pajak hotel dan pajak restoran merupakan salah satu komponen yang penting pada Pendapatan Asli Daerah (PAD). Data yang digunakan dalam penelitian ini adalah sekunder.Data yang diperoleh dari Dinas Pendapatan Daerah Kabupaten Bojonegoro. Metode pengumpulan data yang digunakan adalah metode dokumentasi dan Library Research dengan analisis perhitungan efektivitas Pajak Hotel dan Pajak Restoran di Kabupaten Bojonegoro. Hasil penelitian menunjukan bahwa trend penerimaan dan efektivitas Pajak Hotel dan Pajak Restoran bervariasi. Tingkat efektivitas Pajak Hotel yang tertinggi pada tahun 2019 sebesar $144 \%$ dan terendah pada tahun 2016 sebesar $80 \%$, secara keseluruhan trend penerimaan pajak hotel setiap tahunnya mengalami peningkatan dan penurunan. Sedangkan Pajak Restoran di Kabupaten Bojonegoro tertinggi pada tahun 2016 sebesar $408 \%$, terendah pada tahun 2020 sebesar $134 \%$, hasil ini termasuk dalam kriteria sangat efektif karena $>100 \%$.
\end{abstract}

Kata kunci: Realisasi penerimaan, efektivitas pajak hotel dan pajak restoran

\section{ANALYSIS OF TAX REVENUE TRENDS AND EFFECTIVENESS HOTEL AND RESTAURANT TAX IN BOJONEGORO DISTRICT IN 2016-2020 (Case Study at the Regional Revenue Service of Bojonegoro Regency)}

\begin{abstract}
This research aims to analysis receipts trend, effectiveness of hotel tax and restaurant tax at Bojonegoro Regency of 2016 to 2020. Hotel tax and restaurant tax is one of element ( PAD).The data used in this secondary. The secondary data were obtained from (PAD) Bojonegoro Regency. Collecting Method data was dekumentation and library reseach with analysis effectiveness hotel tax and restaurant tax in Bojonegoro Regency. The result showed the effectiveness of hotel tax and restaurant tax vary widley. The hignest level of effectiveness in 2019 amounted to $144 \%$ and the lowest in 2016 amounted $80 \%$, overall the hotel tax effectiveness each year have increased and decreased. Whereas restaurant tax in Bojonegoro Regency the hignes level of effectiveness in 2016 amonted to $408 \%$, the lowest in 2020 amounted $134 \%$. Effectiveness restaurant tax show that efektif because $>100 \%$
\end{abstract}

Keywords: The realization of receipts, effectiveness hotel tax and restaurant tax 


\section{PENDAHULUAN}

Penerimaan PAD salah satu berasal dari sektor pajak daerah. Pajak daerah merupakan salah satu sumber Pendapatan Asli Daerah yang dipungut dari masyarakat tanpa mendapatkan imbalan langsung. Hal ini sesuai dengan UU No. 28 Tahun 2009 tentang Pajak Daerah dan Retribusi Daerah yang mengungkapkan bahwa Pajak Daerah adalah iuran wajib yang dilakukan oleh orang pribadi atau badan kepada daerah tanpa imbalan langsung yang seimbang, yang dapat dipaksakan berdasarkan peraturan perundang-undangan yang berlaku, yang digunakan untuk membiayai penyelenggaran daerah dan pembangunan daerah. Dengan menggali serta meningkatkan perolehan pajak daerah yang ada di daerah tersebut, maka PAD nantinya dapat digunakan untuk pembangunan serta meningkatkan kesejahteraan rakyat. Pajak Daerah terbagi menjadi dua, yaitu pajak Propinsi dan pajak Kabupaten. Pajak Propinsi terdiri dari Pajak Kendaraan Bermotor dan Kendaraan di Atas Air, Pajak Bea Balik Nama Kendaraan Bermotor, serta Pajak Pengambilan dan Pemanfaatan Air Bawah Tanah dan Air Permukaan. Sedangkan Pajak Kabupaten/Kota terdiri dari Pajak Hotel, Pajak Restoran, Pajak Hiburan, Pajak Reklame, Pajak Penerangan Jalan, Pajak Pengambilan Bahan Galian Golongan C dan Pajak Parkir.Pajak bagi pemerintah daerah berperan sebagai sumber pendapatan (budgetary function) yang utama dan juga sebagai alat pengatur (regulatory function).

Pajak sebagai salah satu sumber pendapatan daerah yang digunakan untuk membiayai pengeluaran-pengeluaran pemerintah, seperti membiayai administrasi pemerintah, membangun dan memperbaiki infrastruktur, menyediakan fasilitas pendidikan dan kesehatan, dan membiayai kegiatan pemerintah daerah dalam menyediakan kebutuhan-kebutuhan yang tidak dapat disediakan oleh pihak swasta yaitu berupa barang-barang publik.
Pajak daerah berperan serta dalam membiayai pembangun daerah, tanpa adanya pajak daerah, maka kebutuhan akan dana untuk pembangunan lebih sulit untuk di penuhi karena seperti yang kita ketahui bahwa sebagian besar pendapatan daerah kita adalah berasal dari pajak, terutama pajak daerah.

Salah satu jenis pajak daerah yang semakin berkembang di Kabupaten Bojonegoro adalah Pajak Hotel dan Pajak Restoran yang ditetapkan oleh daerah untuk kepentingan pembiayaan daerah tersebut.

Letak Kabupaten Bojonegoro yang strategis sebagai Kabupaten perdagangan, jasa, industri, akan mendorong tumbuh kembangnya industri rumah makan maupun perhotelan atau jasa penginapan. Perkembangan industri rumah makan dan perhotelan secara langsung maupun tidak langsung akan berdampak pada peningkatan Pendapatan Asli Daerah.

Dimana penerimaan pajak hotel maupun pajak restoran berperan penting dalam menyokong pembangunan daerah itu sendiri, seperti pemasukan dana yang sangat potensial karena besarnya penerimaan pajak akan meningkatkan laju pertumbuhan penduduk, perekonomian dan stabilitas politik.

\section{LANDASAN TEORI}

\section{Pengertian Pajak}

Menurut Chandra (2020:2) menyatakan bahwa : "Pajak adalah kontribusi wajib kepada negara yang terutang oleh orang pribadi atau badan yang bersifat memaksa berdasarkan Undang-Undang, dengan tidak mendapatkan imbalan secara langsung dan digunakan untuk keperluan negara bagi sebesar-besarnya kemakmuran rakyat. Membayar pajak bukan hanya merupakan kewajiban, tetapi merupakan hak dari setiap warga negara untuk ikut berpartisipasi dalam bentuk peran serta terhadap pembiayaan negara dan pembangunan nasional. Tanggung jawab atas kewajiban pembayaran pajak, sebagai pencerminan kewajiban kenegaraan dibidang perpajakan 
berada pada anggota masyarakat sendiri untuk memenuhi kewajiban tersebut.

Menurut Hartati (2020:389) pajak adalah iuran dari rakyat kepada negara berdasarkan Undang-undang yang dapat di paksakan dengan tiada mendapat jasa imbalan (interpretasi) secara langsung yang dapat ditunjukkan dan digunakan untuk kepentingan umum.

Menurut Idris (2019:6) Pajak adalah iuran wajib berupa uang atau barang yang dipungut oleh penguasa berdasarkan normanorma hukum, guna menutup biaya produksi barang-barang dan jasa kolektif dalam mencapai kesejahteraan umum.

Menurut Sutedi (2018:2) “ Pajak adalah iuran rakyat kepada kas negara berdasarkan Undang-undang sehingga dapat dipaksakan dengan tidak mendapat balas jasa secara langsung.

Menurut Mardiasmo (2016:1) "Pajak adalah iuran rakyat kepada kas negara berdasarkan undang-undang (yang dapat dipaksakan) dengan tiada mendapat jasa timbal (kontraprestasi) yang langsung dapat ditunjukkan dan yang digunakan untuk membayar pengeluaran umum".

Menurut Rahayu (2010:21) istilah pajak berasal dari bahasa jawa yaitu "ajeg" yang berarti pungutan teratur pada waktu tertentu. Kemudian berangsur-angsur mengalami perubahan, maka sebutan semula ajeg menjadi sebutan pa-ajeg memiliki arti sebagai pungutan yang dibebankan kepada rakyat secara teratur, terhadap hasil bumi. Pungutan tersebut sebesar 40 persen dari yang dihasilkan petani untuk diserahkan kepada raja dan pengurus desa. Penentuan besar kecilnya bagian yang diserahkan tersebut hanyalah berdasarkan adat kebiasaan semata yang berkembang pada saat itu.

Menurut Suandy (2018:9) Pajak adalah bantuan, baik secara langsung maupun tidak, yang dipaksakan oleh kekuasaan publik dari penduduk atau dari barang, untuk menutup belanja pemerintah.

\section{Fungsi Pajak}

Menurut Rahayu (2010:25) Fungsi pajak adalah kegunaan pokok dan manfaat pokok pajak. Umumnya dikenal dengan 2 macam.

Fungsi Budgetair.

Fungsi Regulered

\section{Syarat Pemungutan Pajak}

Menurut Mardiasmo (2016:2) agar pemungutan pajak tidak menimbulkan hambatan atau perlawanan, maka pemungutan pajak harus memenuhi syarat sebagai berikut:

Pemungutan Pajak Harus Adil (Syarat Keadilan)

Pemungutan Pajak harus Berdasarkan Undang-Undang (Syarat Yuridis

Tidak Menganggu Perekonomian (Syarat Ekonomis).

Pemungutan Pajak harus Efisien (Syarat Finansial).

Sistem pemungutan pajak harus sederhana.

\section{Pajak Daerah}

Menurut Chandra (2015:442) menyatakan bahwa pajak daerah adalah kontribusi wajib kepada daerah yang terutang oleh orang pribadi atau badan yang bersifat memaksa berdasarkan Undang-Undang, dengan tidak mendapatkan imbalan serta langsung dan digunakan untuk keperluan daerah bagi sebesar-besarnya kemakmuran rakyat. Pajak daerah meliputi pajak Propinsi dan pajak Kabupaten.

\section{Pajak Provinsi, terdiri atas:}

Pajak kendaraan bermotor dan kendaraan di atas air

Bea balik nama kendaraan bermotor dan kendaraan di atas air

Pajak bahan bakar kendaraan

Pajak rokok

Pajak pengambilan dan pemanfaatan air bawah tanah dan air permukaan

Jenis pajak kabupaten/kota meliputi:

Pajak air

Pajak pengambilan bahan galian golongan

Pajak hiburan

Pajak sarang burung walet

Pajak parkir

Pajak hotel

Pajak restoran 
Pajak bea perolehan hak atas tanah dan bangunan (BPHTB).

Pajak bumi dan bangunan perdesaan dan perkotaan (PBB-P2)

\section{Trend}

Menurut Roro Bella (2014) trend yaitu pertumbuhan atau kondisi pendapatan pada suatu perusahaan baik kecenderungan akan naik, turun maupun tetap.

\section{Efektivitas}

Menurut Handayani (2013) Efektivitas adalah perbandingan antara realisasi suatu pendapatan dengan target yang ditetapkan. Dengan kata lain efektivitas berarti tingkat pencapaian hasil program kerja dengan target yang ditetapkan, juga bisa dikatakan merupakan perbandingan antara outcome dengan output.

Untuk menghitung efektivitas pengelolaan pajak Hotel dan Restoran digunakan rumus sebagai berikut :

Efektivitas $=($ Realisasi Penerimaan Pajak)/(Target Penerimaan Pajak) x 100\%

Dari pengertian efektivitas tersebut disimpulkan bahwa efektivitas bertujuan untuk mengukurr rasio keberhasilan, semakin besar rasio maka semakin efektif, standar minimal rasio keberhasilanadalah $100 \%$ atau 1 (satu) dimana realisasi sama dengan target yang telah ditentukan. Menurut Putri, dkk (2013) Tingkat efektivitas dapat digolongkan kedalam beberapa kategori yaitu sebagai berikut.

Koefisien efektivitas bernilai diatas $100 \%$ berarti sangat efektif

Koefisien efektivitas bernilai antar 90\%$100 \%$ berarti efektif

Koefisien efektivitas bernilai antar 80\%- 90 $\%$ berarti cukup efektif

Koefisien efektivitas bernilai antar 60\%- 80 $\%$ berarti kurang efektif

Koefisien efektivitas bernilai dibawah $60 \%$ berarti tidak efektif

\section{Pajak Hotel}

Sesuai dengan Undang-Undang Nomor 28 Tahun 2009 Pasal 1 angka 20 dan 21, Pajak Hotel adalah pajak atas pelayanan yang disediakan oleh hotel. Sedangkan yang dimaksud dengan hotel adalah fasilitas penyedia jasa penginapan/ peristirahatan.

\section{Dasar Hukum Pemungutan Pajak Hotel}

Menurut tundong, karamoy (2013) menyebutkan, Pemungutan Pajak Hotel di Indonesia saat ini didasarkan pada dasar hukum yang jelas dan kuat, sehingga harus dipatuhi oleh masyarakat dan pihak yang terkait. Dasar hukum pemungutan pajak hotel pada suatu Kabupaten adalah sebagai berikut.

Undang-Undang Nomor 28 Tahun 2009 tentang Pajak Daerah dan Retribusi Daerah. Undang-Undang Nomor 34 Tahun 2000 yang merupakan perubahan atas UndangUndang Nomor 18 Tahun 1997 tentang Pajak Daerah dan Retribusi Daerah.

Peraturan Pemerintah Nomor 65 Tahun 2001 tentang Pajak Daerah.

Peraturan Daerah Kabupaten/Kota yang mengatur tentang Pajak Hotel.

Keputusan Bupati/Walikota yang mengatur tentang Pajak Hotel sebagai aturan pelaksanaan Peraturan Daerah tentang Pajak Hotel pada kabupaten.

\section{Objek dan Subjek Pajak Hotel}

Menurut Chandra (2013:450) Objek pajak adalah pelayanan yang disediakan hotel dengan pembayaran, termasuk jasa penunjang sebagai kelengkapan hotel yang sifatnya memberi kemudahan dan kenyamanan (fasilitas olahraga dan hiburan, fasilitas telepon, fax, teleks, internet, fotocopi, pelayanan cuci, setelika, transportasi, dan fasilitas sejenis). Objek pajak terkecuali :

Jasa tempat tinggal asrama yang diselenggarakan oleh pemerintah/pemda.

Jasa sewa apartemen, kondominium, dan sejenisnya.

Jasa tempat tinggal di pusat pendidikan atau kegiatan keagamaan.

Jasa tempat tinggal di rumah sakit, asrama perawat, panti jompo, panti asuhan, dan panti sosial lainnya yang sejenis

Jasa biro perjalanan/ wisata yang diselenggarakan hotel dapat dimanfaatkan umum.

\section{Dasar Pengenaan Pajak Hotel}

Menurut Sari (2017) Besarnya Pajak Hotel yang terutang dihitung dengan cara 


\section{SULTANIST: Jurnal Manajemen dan Keuangan, Vol 8 (2), 2020}

mengalikan tarifpajak dengan dasar pengenaan pajak. Secara umum perhitungan Pajak Hotel adalah sesuai dengan rumus berikut:

Pajak Terutang = Tarif Pajak $\mathrm{x}$ Dasar Pengenaan Pajak $=$ Tarif Pajak $\mathrm{x}$ Jumlah Pembayaran atau yang seharusnya dibayar Kepada Hotel.

\section{Pajak Restoran}

Menurut Chandra (2013:451) Pajak Restoran adalah pajak atas pelayanan restoran. Restoran adalah fasilitas penyedia makanan dan atau minuman dengan dipungut bayaran yang mencakup juga rumah makan, kafetaria, kantin, warung, bar dan sejenisnya termasuk jasa boga/ketering. Dasar Hukum Pemungutan Pajak Restoran Undang-undang Nomor 28 Tahun 2009 yang merupakanperubahan atas undangundang Nomor 34 Tahun 2000 tentang Pajak Dartah dan Retribusi Daerah.

Peraturan Pemerintah Nomor 91 Tahun 2010 tentang self and official assesment

\section{Objek dan Subjek Pajak Restoran}

Menurut Chandra (2013:451) pajak yang disediakan oleh restoran (meliputi pelayanan penjualan makanan dan minuman yang dikonsumsi pembeli, baik dikonsumsi ditempat pelayanan maupun ditempat lain). Tidak termasuk objekpajak Restoran adalah pelayanan yang disediakan oleh restoran yang nilai penjualannya tidak melebihi batas tertentu yang ditetapkan dengan Peraturan Daerah. Sedangkan subjek pajak adalah orang pribadi atau badan yang membeli makanan dan/atau minuman dari restoran. Secara sederhana subjek pajak adalah konsumen yang menikmati pelayanan yang diberikan oleh restoran tersebut. Sementara itu, wajib pajak adalah orang pribadi atau badan yang mengusahakan restoran.

\section{Dasar Pengenaan Pajak Restoran}

Jumlah pembayaran yang diterima atau yangseharusnya diterima restoran. Selanjutnya tarif Pajak Restoran ditetapkan paling tinggi sebesar (10\%) sepuluh persen dan ditetapkan dengan peraturan daerah yang bersangkutan. Hal ini dimaksudkan untuk memberikan keleluasaan kepada pemerintah kabupaten untuk menetapkan tarif pajak yangdipandang sesuai dengan kondisi masing masing daerah Kabupaten. Dengan demikian, setiap daerah Kabupaten diberi kewenangan untuk menetapkan besarnya tarif pajak yang mungkin berbeda dengan Kabupaten lainnya. (Handayani, 2020)

Besarnya pokok Pajak Restoran yang terutang dihitung dengan cara mengalikan tarif pajakdengan dasar pengenaan pajak. Secara umum perhitungan Pajak Restoran adalah sesuai denga rumus berikut:

Pajak Terutang $=$ Tarif Pajak $\mathrm{x}$ Dasar Pengenaan Pajak

\section{Penelitian Terdahulu}

Tundoong, dkk (2015) dengan judul "Analisis Efektivitas Penerimaan Pajak Hotel Dan Kontribusinya Terhadap Pajak Daerah Di Kota Kotamobagu". Metode analisis yang digunakan adalah metode kuantitatif. Hasil penelitian menunjukkan bahwa Target dan realisasi penerimaan pajak daerah Kota Kotamobagu mengalami peningkatan dari tahun 2010 hingga 2014. Realisasi penerimaan pajak daerah selalu melebihi target disetiap tahunnya. Tingkat efektivitas pajak hotel di Kota Kotamobagu sudah efektif. Hal ini terlihat dari tingkat efektivitas pada tahun 2010 yang mencapai $92,44 \%$ dan meningkat hingga 106,39\% ditahun 2014.

Putri, dkk (2015) dengan judul "Analisis penerimaan pajak hotel, pajak restoran, pajak hiburan Sebagai sumber pendapatan asli daerah". Metode yang digunakan dalam penelitian ini adalah metode kuantitatif. Hasil menunjukkan Tingkat kontribusi penerimaan pajak hotel dalam kurun waktu 8 (delapan) tahun periode 2006-2013 terhadap pendapatan asli daerah berturutturut adalah 5,32\%, 4,06\%, 5,47\%, 5,66\%, $6,46 \%, 4,38 \%, 4,25 \%$ dan $5,84 \%$. Rata-rata kontribusi penerimaan pajak hotel terhadap pendapatan asli daerah yaitu sebesar 5,18\%. Persentase rata-rata kontribusi penerimaan yang telah di capai oleh Kota Malang dari tahun 2006-2013. Tingkat efektivitas pajak hotel dalam kurun waktu 8 (delapan) tahun periode 2006-2013 berturut-turut yaitu 
$106,96 \%, 101,04 \%, 103,63 \%, 102,33 \%$, $111,02 \%, 102,51 \%, 109,81 \%$ dan $125,37 \%$. Rata-rata efektivitas pajak hotel yaitu sebesar 107,8\%. Persentase efektivitas menunjukkan tingkat efektivitas berada pada kriteria sangat efektif dari tahun 2008-2013. Zuhri (2016) dengan judul "Analisis efisiensi dan efektivitas pemungutan pajak restoran di kota padang". Metode yang digunakan dalam penelitian ini adalah metode deskriptif kuantitatif. Hasil penelitian menunjukkan bahwa Pemungutan pajak restoran dikota padang selama 2 tahun mulai tahun 2009-2010 telah menunjukkan hasil yang baik.

\section{METODE}

Pendekatan penelitian yang digunakan adalah penelitian deskriptif kualitatif. Penelitian deskriptif merupakan kegiatan pengumpulan data. Kualitatif merupakan metode penelitian yang digunakan untuk peneliti pada kondisi objek yang alamiyah, dimana peneliti adalah sebagai instrumen kecil, teknik pengumpulan data yang dilakukan secara gabungan, analisis data bersifat indukatif/ kualitatif, dan hasil penelitian kualitatif lebih menekankan makna dari pada generalisasi (Sugiono, 2015:9).

\section{HASIL DAN PEMBAHASAN}

\section{Hasil Penelitian}

\section{Perhitungan Efektivitas Pajak Hotel}

Efektivitas $=\frac{\text { Realisasi Penerimaan Pajak hotel }}{\text { Target Penerimaan Pajak hotel }} \times 100 \%$

a. Tahun 2016

Berdasarkan realisasi penerimaan pajak hotel sebesar Rp.212.833.300 diketahui efektivitas pajak hotel di Kabupaten Bojonegoro tahun 2016 dengan target pajak hotel sebesar Rp.266.172.00 tahun 2016 adalah sebagai berikut :
Efektivitas tahun $2016=\frac{212.833 .300}{266.172 .000} \times 100 \%=80 \%$

Dari hasil perhitungan diatas diperoleh tingkat efektivitas pajak hotel di Kabupaten Bojonegoro pada tahun 2016 adalah $80 \%$

b. Tahun 2017

Berdasarkan realisasi penerimaan pajak hotel sebesar Rp.284.944.042 diketahui efektivitas pajak hotel di Kabupaten Bojonegoro tahun 2017 dengan target pajak hotel sebesar Rp.275.000.000 tahun 2017 adalah sebagai berikut :

Efektivitas tahun $2017=\frac{284.944 .042}{275.000 .000} \times 100 \%=104 \%$

Dari hasil perhitungan diatas diperoleh tingkat efektivitas pajak hotel di Kabupaten Bojonegoro pada tahun 2017 adalah $104 \%$.

c. Tahun 2018

Berdasarkan realisasi penerimaan pajak hotel sebesar Rp.450.062.500 diketahui efektivitas pajak hotel di Kabupaten Bojonegoro tahun 2018 dengan target pajak hotel sebesar Rp.399.199.999 tahun 2018 adalah sebagai berikut :

Efektivitas tahun $2018=\frac{450.062 .500}{399.199 .999} \times 100 \%=89 \%$

Dari hasil perhitungan diatas diperoleh tingkat efektivitas pajak hotel di Kabupaten Bojonegoro tahun 2018 adalah $89 \%$.

d. Tahun 2019

Berdasarkan realisasi penerimaan pajak hotel sebesar Rp.2.521.031.535 diketahui efektivitas pajak hotel di Kabupaten Bojonegoro tahun 2019 dengan target pajak hotel sebesar Rp.1.755.000.000 tahun 2019 adalah sebagai berikut :

Efektivitas tahun $2019=\frac{2.521 .031 .535}{1.755 .000 .000} \times 100 \%=144 \%$ 
Dari hasil perhitungan diatas diperoleh tingkat efektivitas pajak hotel di Kabupaten Bojonegoro tahun 2019 adalah $144 \%$.

e. Tahun 2020

Berdasarkan realisasi penerimaan pajak hotel sebesar Rp.4.687.488.021 diketahui efektivitas pajak hotel di Kabupaten Bojonegoro tahun 2020 dengan target pajak hotel sebesar Rp.3.800.000.000 tahun 2020 adalah sebagai berikut :

$$
\text { Efektivitas tahun } 201=\frac{4.687,488.021,00}{3.800,000,000} \times 100 \%=123 \%
$$

Dari hasil perhitungan diatas diperoleh tingkat evektifitas pajak hotel di Kabupaten Bojonegoro tahun 2020 adalah $123 \%$

Dari hasil perhitungan di atas dapat dilihat tingkat efektivitas pajak hotel Kabupaten Bojonegoro pada tahun 2016 - 2020 cenderung naik turun yaitu pada tahun 2016 efektivitas pajak hotel cukup efektif dengan presentase sebesar $80 \%$, dan mengalami kenaikan lagi pada tahun 2017 dengan presentase 104 $\%$ yang memiliki kriteria sangat efektif. Pada tahun 2018 mengalami penurunan dengan presentase $89 \%$. Tetapi pada tahun 2019 mengalami kenaikan yang sangat tinggi yaitu sebesar $144 \%$ dengan kriteria sangat efektif, sedangakan tahun 2020 mengalami penurunan sebesar $123 \%$.

\section{Perhitungan Efektivitas Pajak Restoran}

Efektivitos $=\frac{\text { Realisasi Penerimaan Pajak Restoran }}{\text { Target Penerimaan Pajak Restoran }} \times 100 \%$

a. Tahun 2016

Berdasarkan realisasi penerimaan pajak restoran sebesar Rp.640.436.798 diketahui efektivitas pajak restoran di Kabupaten Bojonegoro tahun 2016 dengan target penerimaan pajak restoran sebesar Rp.157.020.000 tahun 2016 adalah sebagai berikut :

Efektivitas tahun $2016=\frac{640.436 .798}{157,020.000} \times 100 \%=408 \%$

Dari hasil perhitungan diatas diperolrh tingkat efektivitas pajak restoran di Kabupaten Bojonegoro tahun 2016 adalah $408 \%$

b. Tahun 2017

Berdasarkan realisasi penerimaan pajak restoran sebesar Rp.1.418.215.131 diketahui efektivitas pajak hotel di Kabupaten Bojonegoro tahun 2017 dengan target pajak hotel sebesar Rp.705.114.000 tahun 2017 adalah sebagai berikut :

efektivitas tahun 2017 $=\frac{1.418 .215 .131}{705.144 .000} \times 100 \%=201 \%$

Dari perhitungan diatas diperoleh tingkat efektivitas pajak restoran di Kabupaten Bojonegoro tahun 2017 adalah $201 \%$

c. Tahun 2018

Berdasarkan realisasi penerimaan pajak restoran sebesar Rp.2.154.802.005 diketahui efektivitas pajak restoran di Kabupaten Bojonegoro tahun 2018 dengan target pajak hotel sebesar Rp.1.450.215.000 tahun 2018 adalah sebagai berikut :

efektivitas tahun $2018=\frac{2,154,802,005}{1.450,215,000} \times 100 \%=149 \%$

Dari perhitungan diatas diperoleh tingkat efektivitas pajak restoran di Kabupaten Bojonegoro tahun 2018 adalah $149 \%$

d. Tahun 2019

Berdasarkan realisasi penerimaan pajak restoran sebesar Rp. 3.244.887.931diketahui efektivitas pajak hotel di Kabupaten Bojonegoro tahun 2019 dengan target pajak hotel sebesar Rp.1.556.892.492 tahun 2019 adalah sebagai berikut : 
Efektivitas tahun $2019=\frac{3.244 .887 .931}{1.556 .892 .492} \times 100 \%=208 \%$

Dari perhitungan diatas diperoleh tingkat efektivitas pajak restoran di Kabupaten Bojonegoro tahun 2019 adalah $208 \%$

e. Tahun 2020

Berdasarkan realisasi penerimaan pajak restoran sebesar Rp.5.267.168.167 diketahui efektivitas pajak hotel di Kabupaten Bojonegoro tahun 2020 dengan target pajak hotel sebesar Rp.3.928.141.293 tahun 2019 adalah sebagai berikut :

Efektivitas tahun $2020=\frac{5.267 .168 .167}{3.928 .144 .293} \times 100 \%=134 \%$

Dari perhitungan diatas diperoleh tingkat efektivitas pajak restoran di Kabupaten Bojonegoro tahun 2020 adalah $134 \%$

Dari hasil perhitungan diatas dapat dilihat bahwa tingkat efektivitas pajak hotel Kabupaten Bojonegoro tahun 20162020 selalu mengalami kenaikan pada setiap tahunnya, yaitu pada tahun 2016 efektivitas pajak restoran sebesar $408 \%$ dan merupakan efektivitas tertinggi selama kurun waktu 2016-2020. Sedangkan pada tahun 2017 tingkat efektivitas mengalami penurunan sebesar $201 \%$, kemudian pada tahun 2018 juga mengalami penurunan sebesar $149 \%$. Tapi pada tahun 2019 mengalami kenaikan sebesar $208 \%$, tahun 2020 mengalami penurunan sebesar $134 \%$.

Dengan melihat rata -rata efektivitas pajak restoran Kabupaten Bojonegoro yang melebihi $100 \%$ atau rata-rata sebesar $149 \%$ setiap tahunnya, hal ini menunjukkan bahwa kinerja dalam pemungutan pajak restoran Kabupaten Bojonegoro sangat baik, karena realisasi pajak restoran lebeih besar dari pada target yang direncanakan, berarti sangat efektif. Efektivitas terbesar tahun 20162020 terjadi pada tahun 2016 sebesar 408 $\%$.

Hal ini disebabkan intensifikasi pemungutan pajak restoran rutin dilaksanakan, sedangkan untuk tahun 2020 efektifitas sebesar $134 \%$, efektifitas tersebut terkecil di kurun waktu tahun 2016-2020.

\section{Pembahasan}

Efektivitas Pajak Hotel Kabupaten Bojonegoro

Dari semua hasil perhitungan efektivitaas pajak hotel yang di peroleh dari tahun 2016-2020 dapat dilihat pada tabel 4.6.

Tabel 1 Efektivitas Pajak Hotel di

Kabupaten Bojonegoro Tahun 2016-2020

\begin{tabular}{|l|l|l|}
\hline Tahun & $\begin{array}{l}\text { Presentas } \\
\mathrm{i}\end{array}$ & Kriteria \\
\hline 2016 & $80 \%$ & $\begin{array}{l}\text { Cukup } \\
\text { Efektif }\end{array}$ \\
\hline 2017 & $104 \%$ & $\begin{array}{l}\text { Sangat } \\
\text { Efektif }\end{array}$ \\
\hline 2018 & $89 \%$ & $\begin{array}{l}\text { Cukup } \\
\text { Efektif }\end{array}$ \\
\hline 2019 & $144 \%$ & $\begin{array}{l}\text { Sangat } \\
\text { Efektif }\end{array}$ \\
\hline 2020 & $123 \%$ & $\begin{array}{l}\text { Sangat } \\
\text { Efektif }\end{array}$ \\
\hline
\end{tabular}

Sumber : Dispenda Kab Bojonegoro, 2020

Efektivitas pajak hotel di Kabupaten Bojonegoro yang menunjukkan bahwa pemungutan dan pengelolaan pajak hotel di Kabupaten Bojonegoro sudah efektif. Walaupun pada tahun 2016 dan 2018 termasuk kreteria cukup.

Efektivitas Pajak Restoran Kabupaten Bojonegoro

Dari hasil lima tahun ini efektivitas pajak hotel yang diperoleh diketahui bahwa efektivitasnya sangat efektif. 
Untuk lebih jelasnya dapat dilihat pada tabel 4.7

Tabel 2 Efektivitas Pajak Restoran di Kabupaten Bojonegoro 2016-2020

\begin{tabular}{|c|c|c|}
\hline Tahun & Presentase & Kriteria \\
\hline 2016 & $408 \%$ & $\begin{array}{l}\text { Sangat } \\
\text { efektif }\end{array}$ \\
\hline 2017 & $201 \%$ & $\begin{array}{l}\text { Sangat } \\
\text { efektif }\end{array}$ \\
\hline 2018 & $149 \%$ & $\begin{array}{l}\text { Sangat } \\
\text { efektif }\end{array}$ \\
\hline 2019 & $208 \%$ & $\begin{array}{l}\text { Sangat } \\
\text { efektif }\end{array}$ \\
\hline 2020 & $134 \%$ & $\begin{array}{l}\text { Sangat } \\
\text { efektif }\end{array}$ \\
\hline
\end{tabular}

Sumber :Dispenda Kab. Bojonegoro, 2020

Efektivitas Pajak Restoran di Kabupaten Bojonegoro yang menunjukkan bahwa pemungutan dan pengelolaan Pajak Restoran di Kabupaten Bojonegoro terlihat sangat melebihi 100 \%. Pada tahun 2016 realisasi penerimaan pajak restoran di Kabupaten Bojonegoro sebesar Rp.640.436.798 mengalami penurunan dibandingkan dengan tahun 2017 yang penerimaannya sebesar Rp.1.418.215.131. hal ini terjadi disebabkan semakin bertambahnya jumlah restoran pada setisp tshunnys. Pada tahun 2018-2020 selalu terjadi kenaikan lagi realisasi penerimaannya. Jadi efektivitas pajak restoran dari kurun waktu 2016-2020 sangat efektif.

\section{Trend Penerimaan Pajak Hotel Kabupaten Bojonegoro}

Melihat trend penerimaan dari grafik pajak hotel di atas, dapat dilihat penerimaan pajak hotel dalam lima tahun tersebut diketahui bahwa terdapat 2 tahun dimana tahun tersebut mengalami kreteria cukup efektif, yaitu tahun 2016 dengan presentase $80 \%$ dimana realisasi yang diterima lebih kecil dari target yang ditentukan. Tahun 2018 presentase nya $89 \%$ sama hal nya dengan tahun 2016 dimana target yang ditentukan tidak sesuai dengan realisasi penrimaan. Sedangkan pada tahun 2017, 2019 dan 2020 mendapat kriteria yang sangat efektif, dimana tahun-tahun itu menpunyai kriteria diatas $100 \%$ lebih. Sehingga dapat disimpulkan bahwa trend penerimaan pajak hotel di Kabupaten Bojonegoro mengalami kenaikan dan penurunan. Jadi pemungutan pajak hotel dan pajak restoran Kabupaten Bojonegoro lebih di tingkatkan. Lebih jelasnya dapat dilihat pada grafik di bawah ini.

\section{Trend Penerimaan Pajak Restoran Kabupaten Bojonegoro}

Melihat trend penerimaan pajak restoran yang menunjukkan bahwa penerimaan pada setiap tahunnya selalu meningkat, realisasi yang di terima lebih besar dari target yang ditetapkan. Meskipun trend pada pada pajak restoran masih naik turun tetapi tetap saja lebih besar realisasi penerimaan dibandingkan target Pajak Restoran yang di tetapkan Pemerintah Kabupaten Bojonegoro. Berikut trend penerimaan pajak restoran 


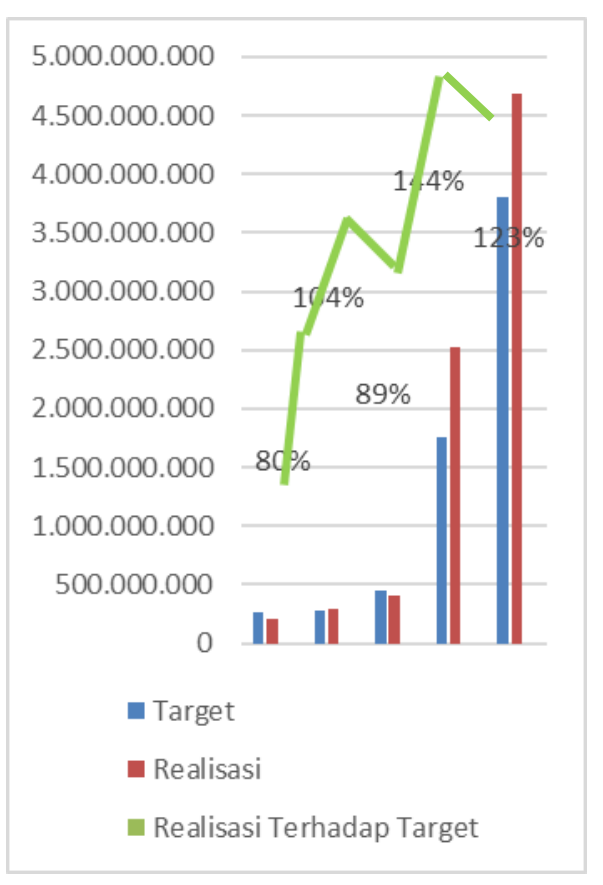

Grafik 1 Trend Penerimaan Pajak Hotel di Kabupaten Bojonegoro tahun 2016-2020

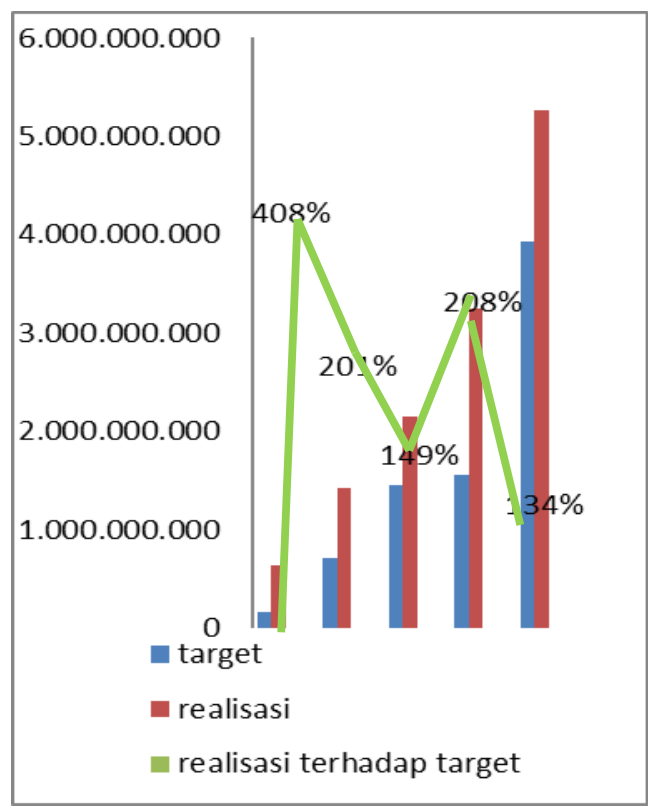

Grafik 2 Trend Penerimaan Pajak Restoran Di Kabupaten Bojonegoro Tahun 2016-2020

Hasil penelitian ini mendukung dari penelitian terdahulu yang dilakukan oleh Fikri Zuhri (2016) dengan judul “ Analisis Efisiensi Dan Efektivitas Pemungutan Pajak Restoran Di Kota Padang Tahun 2009-2016", yang telah menunjukkan hasil yang sangat efektif. Mendukung pula pada penelitian terdahulu yang dilakukan oleh Putri, dkk (2019) dengan judul " Analisis Penerimaan Pajak Hotel Dan Pajak Restoran Sebagai Sumber Pendapatan Asli Daerah Tahun 2006-2018 " yang menunjukkan tingkat efektivitasnya berada pada kreteria sangat efektif.

\section{SIMPULAN DAN SARAN}

\section{Simpulan}

Berdasarkan hasil penelitian dan analisis tersebut, maka dapat diambil beberapa kesimpulan, antara lain :

1. Selama priode 2016 hingga tahun 2020, target dan realisasi trend penerimaan Pajak Hotel dan Pajak Restoran selalu mengalami peningkatan dan penurunan.

2. Tingkat efektifitas pajak hotel di Kabupaten Bojonegoro pada tahun 2016-2020 sangat efektif. Dengan melihat rata-rata efektivitas pajak hotel Kabupaten Bojonegoro yang melebihi $100 \%$.

3. Tingkat efektifitas pajak restoran di Kabupaten Bojonegoro pada tahun 2016-2020 sangat efektif. Dengan melihat efektivitas pajak restoran yang melebihi $100 \%$ atau rata-rata sebesar 148, $59 \%$ setiap tahunnya, hal ini menunjukkan bahwa kinerja pemungutan pajak restoran di Kabupaten Bojonegoro sangat efektif.

\section{Saran}

Melihat dari trend penerimaan dan efektivitas pajak Hotel dan Pajak Restoran dapat menunjukkan bahwa untuk Pajak Hotel dan Pajak Restoran memiliki penerimaan yang cukup tinggi dan efektifitasnya yang sangat efektif. Untuk itu diperlukan peran pemerintah 
Daerah dan pihak-pihak terkait untuk lebih menekankan wajib pajak dalam pembayaran pajak daerah khususnya Pajak Hotel dan Pajak Restoran sehingga penerimaan terhadap pajak daerah maupun pendapatan asli daerah dapat ditingkatkan lagi. Adapun saran yang dapat disampaikan sebagai berikut.

1. Pemerintah Daerah Kabupaten Bojonegoro khususnya dinas yang terkit harus mengkaji ulang penetapan target penerimaan Pajak Hotel dan Pajak Restoran agar sesuai dengan realisasi.

2. Dalam upaya meningkatkan penerimaan Pajak Hotel dan Pajak Restoran, pemerintah daerah Kabupaten Bojonegoro khususnya Dinas pendapatan dalam menetapkan Pajak Hotel dan Pajak Restoran harus senantiasa melakukan sosialisasi arti pentingnya pajak terhadap pembangunan sehingga wajib pajak sadar membayar pajak.

3. Bagi peneliti selanjutnya untuk meramalkan tahun yang akan mendatang dengan menggunakan analisis trend kuadrat terkecil.

\section{DAFTAR PUSTAKA}

APBD Kabupaten Bojonegoro Tahun 2020

Deliya Tutiwuri Handayani (2017), Analisis

Kontribusi Pajak Hotel dan Restoran Terhadap Pendapatan Asli Daerah (PAD) Kabupaten Ngawi, Tesis, Fakultas Ekonomi, Universitas Sebelas Maret, Surakarta.

Erly Suandy (2018), Hukum Pajak, Cetakan Kedua, Edisi Keempat, Salemba Empat, Yogyakarta.

Fikri Zuhri (2016), Analisis Efisiensi dan Efektivitas Pemungutan Pajak Restoran Di Kota Padang, Skripsi, Fakultas Ekonomi, Universitas Andalas Padang.
Giana Khristy Tundoong, Herman Karamoy (2020), Analisis Efektivitas Penerimaan Pajak Hotel Dan Kontribusinya Terhadap Pajak Daerah Di Kota Kotamobagu, Jurnal EMBA Vol III No.2 Hal 1032-1040.

Gregorius Chandra(2020), Perpajakan Indonesia, Andi, Yogyakarta.

Irlan Fery Idris (2019), Pengantar Perpajakan dengan Teori \& Kasus, Andi, Yogyakarta

Irsandy Octovindo, Nengah Sudjana, Devi Varah Azizah (2019), Analisis Efektivitas dan Kontribusi Pajak Daerah Sebagai Sumber Pendapatan Asli Daerah Kota Batu, Jurnal Administrasi Bisnis (JAB)/ Vol XV No.1

Mardiasmo (2016), Perpajakan, Edisi Revisi, Andi, Yogyakarta.

Neneng Hartati, S.E., M.M (2020), Pengantar Perpajakan, $\mathrm{Cv}$ Pustaka Setia, Bandung.

Peraturan Daerah Nomor. 15 Tahun 2010 Tentang Pendapatan Daerah

Roro Bella Ayu Wandani Prasetio Putri ,dkk (2019), Analisis Penerimaan Pajak Hotel, Pajak Restoran, Pajak Hiburan Sebagai Sumber Pendapatan Asli Daerah, Jurnal Perpajakan, Vol III No.1

Siti Kurnia Rahaya (2010), Perpajakan Indonesia, Graha Ilmu. Yogyakarta

Sugiono (2019), Metode Penelitian Kuantitatif Kualitatif dan $R \& D$, Alfabeta. Bandung.

Sutedi (2018) Hukum Pajak, Sinar Grafika. Jakarta

\section{PROFIL SINGKAT}

Nama Edy Anas Ahmadi. Pendidikan S1 Ekonomi Manajemen lulus pada tahun 2014 dan Pendidikan S2 Manajemen Sumberdaya Manusia lulus Pada tahun 2017. Pekerjaan saat ini sebagai tenaga pendidik yaitu dosen di sekolah tinggi Ekonomi islam permata bojonegoro jawa timur indonesia 